\title{
Coulometric measurement of primary production, with comparison against dissolved oxygen and ${ }^{14} \mathrm{C}$ methods in a seasonal study
}

\author{
Brian Irwin \\ Biological Oceanography Division, Bedford Institute of Oceanography, Dartmouth, Nova Scotia, Canada B2Y 4A2
}

\begin{abstract}
Consumption of carbon dioxide, as measured by direct coulometry in light and dark bottles, was used to estimate the photosynthetic rate of natural assemblages of phytoplankton incubated in situ. A total of 30 experiments were made during a 12 mo peniod in Bedford Basin, Nova Scotia. For comparison, simultaneous estimates of primary production were made on each occasion using both the light-and-darkbottle oxygen method and the ${ }^{14} \mathrm{C}$ method. Primary production values fell in the range $<1$ to $50 \mathrm{mmol} \mathrm{C} \mathrm{m} \mathrm{m}^{-3} \mathrm{~d}^{-1}$. Throughout this range, excellent agreement was found between primary production as estimated by the ${ }^{14} \mathrm{C}$ method and gross primary production estimated by change in dissolved carbon dioxide. Release of labelled carbon into solution accounted for 2 to $19 \%$ of total primary production as measured by the ${ }^{14} \mathrm{C}$ method, with the lower values occurring in the spring bloom period. When the carbon-based results were compared with the oxygen-based ones, they agreed to within a mean apparent photosynthetic quotient of 1.6. High apparent PQ's in winter are attributed to an overestimation of oxygen primary production and an underestimation of ${ }^{14} \mathrm{C}$ primary production. Direct coulometry offers considerable promise as a technique for measuring photosynthesis by phytoplankton.
\end{abstract}

The methods available for measuring primary production may be separated into 2 broad classes (Platt et al. 1989): in vitro methods, where a small sample is incubated in a closed bottle; and bulk property methods, where production is inferred from changes in the chemical properties of the water column. The first class applies to short time scales and discrete depths, the second to longer time scales and a finite interval of depth (Platt 1984). Among the in vitro methods, the ${ }^{14} \mathrm{C}$ method offers the highest precision, but its accuracy has been called into question (Peterson 1980). On the other hand, until recently (Williams \& Jenkinson 1982), the dissolved oxygen method has lacked the precision to make useful measurements at low production rates. Furthermore, uncertainty in the appropriate value of the photosynthetic quotient (PQ) has confounded attempts to verify the oxygen method against ${ }^{14} \mathrm{C}$ (Platt \& Harrison 1986, Smith et al. 1986).

The introduction of a coulometric titration technique to measure changes in dissolved carbon dioxide (Johnson et al. 1985, 1987) offers the possibility of an independent check on the validity of the ${ }^{14} \mathrm{C}$ method. Bender et al. (1987) have compared the ${ }^{14} \mathrm{C}$ method, the coulometric method and the dissolved oxygen methods in a series of experiments on samples drawn from laboratory mesocosms. They concluded that the results for gross production, as measured by the dissolved oxygen and coulometric methods, were similar, but that primary production as measured by the ${ }^{14} \mathrm{C}$ method was an underestimate of gross production. Moreover, the artifacts associated with containment in bottles were small regardless of method.

In this paper, the results are presented of a comparison of all 3 in vitro methods of measuring primary production from a series of observations on natural assemblages of coastal phytoplankton covering a complete annual cycle. Excellent agreement was found between the ${ }^{14} \mathrm{C}$ method and the coulometric method, suggesting the latter as a viable alternative to the former, especially in circumstances where it is not possible or convenient to use radioactive isotopes.

Methods. Sampling: Bedford Basin lies at the inner end of a fjord-like inlet (Halifax Harbour) on the Atlantic coast of Nova Scotia. All samples were collected at a fixed station over the deepest part of the Basin $(75 \mathrm{~m})$ at $44^{\circ} 31.3^{\prime} \mathrm{N}, 63^{\circ} 38.3^{\prime} \mathrm{W}$ between July 1986 and June 1987. Previous studies (Irwin et al. 1983, 1988a, 1988b) have shown this area to have high biomass and production rates especially in spring and summer. Sampling 
frequency was usually once a week except in midwinter (December to February) when both biomass and production rates were extremely low. A Niskin bottle was used to collect water from $1 \mathrm{~m}$ depth, which was then transferred to darkened carboys for immediate dispensing.

Dissolved oxygen method: The light-and-darkbottle method described by Strickland \& Parsons (1972) was used to determine primary production from changes in dissolved oxygen. For each sample 6 light, 5 dark and 4 time-zero bottles were filled by siphoning from the darkened carboys. The time-zero samples, which provided a measure of initial oxygen concentration, were fixed immediately. The dark bottles were wrapped in aluminum foil and maintained at in situ temperature. The light bottles were incubated in situ for $24 \mathrm{~h}$ after which they, and the dark bottles, were fixed.

The high precision method of Williams \& Jenkinson (1982) was used to analyse the oxygen samples. Primary production rates were calculated using the formula for gross production rate given in Strickland \& Parsons (1972):

$$
P_{\mathrm{g}} \mathrm{O}_{2}=[(\text { light bottle })-(\text { dark bottle })] / \text { time }
$$

and expressed as $\mathrm{mmol} \mathrm{O}_{2} \mathrm{~m}^{-3} \mathrm{~d}^{-1}$

${ }^{14} \mathrm{C}$ method: Assimilation of carbon dioxide, measured by the ${ }^{14} \mathrm{C}$ method, was used to determine primary production as outlined in Strickland \& Parsons (1972) and modified by Irwin et al. (1986). To samples in each of 6 light bottles and 4 dark bottles $20 \mu \mathrm{Ci}$ of ${ }^{14} \mathrm{C}$ sodium bicarbonate was added. Light and dark bottles were treated as for the dissolved oxygen method. At the end of the incubation, all the bottles were filtered onto $2.5 \mathrm{~cm}$ Whatman GF/F filters. Prior to assay for radioactivity, the filters were exposed to $\mathrm{HCl}$ fumes to remove inorganic carbon. Aliquots of the filtrate from both light and dark bottles were acidified to remove inorganic ${ }^{14} \mathrm{C}$ and then counted to give estimates of the primary production appearing as dissolved organic carbon (DOC). This label, found in the filtrate $\left({ }^{14} \mathrm{DOC}\right)$, was included with that incorporated into filterable material and the sum used as a basis for computation of primary production by this method. All samples were counted in a liquid scintillation counter with efficiencies determined by the channels ratio method. Production rates were calculated according to Strickland \& Parsons (1972), and expressed as $P^{14} \mathrm{C}\left(\mathrm{mmol} \mathrm{C} \mathrm{m} \mathrm{C}^{-3} \mathrm{~d}^{-1}\right)$.

Coulometric method: Samples for the coulometric method were handled in a similar manner to those for the dissolved oxygen method. For each sample 6 light, 4 dark and 4 time-zero bottles were filled. A single subsample (volume $50 \mathrm{ml}$ ) was titrated from each replicate. No preservatives were added to the samples which were processed immediately after preparation and at the end of the experiment. The initial concentration of carbon dioxide was measured by immediate analysis of the time-zero bottles. Measurement procedure followed that of Johnson et al. (1985) with some modifications. The analytical instruments used were model 5010 Coulometer and model 5030 Carbonate Carbon Apparatus manufactured by Coulometrics Inc. (Golden, Colorado). Titration currents were set at 60 and $2 \mathrm{~mA}$ for the high and low rates respectively. High purity nitrogen gas was used to strip the carbon dioxide from the sample after the addition of phosphoric acid. The flow rate of the carrier gas was $200 \mathrm{ml} \mathrm{min}{ }^{-1}$. The end-point of titration was taken to be the point where the $2 \mathrm{~mA}$ current switched off for the first time. The typical coefficient of variation for replicate samples was consistently around $0.10 \%$ (less than $2 \mu \mathrm{mol} \mathrm{l^{-1 }}$ ). The instrument was calibrated against weighed samples of anhydrous calcium carbonate (Merc cat. \# 2059). This procedure was not required to be repeated frequently because of the stability of the instrument. It was also found that the coulometric solution had to be 'conditioned' by running up to 10 dummy samples before titrating the real samples. Production and respiration rates were calculated using a formula for gross production analogous to that for the dissolved oxygen method:

$$
P_{\mathrm{g}} \mathrm{CO}_{2}=[(\text { dark bottle }) \text { - (light bottle) }] / \text { time }
$$

and expressed as mmol $\mathrm{C} \mathrm{m}^{-3} \mathrm{~d}^{-1}$

Other measurements: Replicate samples for chlorophyll analysis were filtered on each occasion that measurements were made of primary production. Samples for ammonia were taken and analysed immediately; those for nitrate were frozen for later analysis. All samples were analysed by standard techniques as described in Irwin et al. (1986).

Results. Nutrients and biomass: The spring bloom dominates the biological oceanographic process of Bedford Basin. Nitrate concentration decreased rapidly during the bloom from $8 \mathrm{mg}$-at. $\mathrm{m}^{-3}$ to $<1 \mathrm{mg}$-at. $\mathrm{m}^{-3}$ in $7 \mathrm{~d}$ but was measurable at all times of the year (Fig. 1). Ammonia concentrations (Fig.1), were elevated $\left(>4 \mathrm{mg}\right.$-at. $\mathrm{m}^{-3}$ ) at the same time as nitrate concentrations. Chlorophyll biomass peaked at $>$ $24 \mathrm{mg} \mathrm{m}^{-3}$ at the end of the spring bloom. Throughout the remainder of the summer and fall, chlorophyll ranged from 3 to $9 \mathrm{mg} \mathrm{m}^{-3}$ and fell to $<1 \mathrm{mg} \mathrm{m}^{-3}$ in winter (Fig, 2).

Rate measurements: Primary production was maximum during the spring bloom, reaching in excess of $50 \mathrm{mmol} \mathrm{C} \mathrm{m} \mathrm{m}^{-3} \mathrm{~d}^{-1}$. Rates varied between 4 and $36 \mathrm{mmol} \mathrm{C} \mathrm{m} \mathrm{Cd}^{-3}$ through summer and fall and fell to $<2$ in winter (Fig. 2). The contribution of $D O^{14} \mathrm{C}$ to $P^{14} \mathrm{C}$ varied from 2 to $19 \%$, with the lowest values found during the spring bloom (Table 1). Gross oxygen production (Fig. 2), and gross $\mathrm{CO}_{2}$ production (Fig. 2) exhi- 
Fig. 1. Seasonal changes in nitrate and ammonia concentrations in Bedford $\mathrm{Ba}$ sin from July 1986 to June 1987
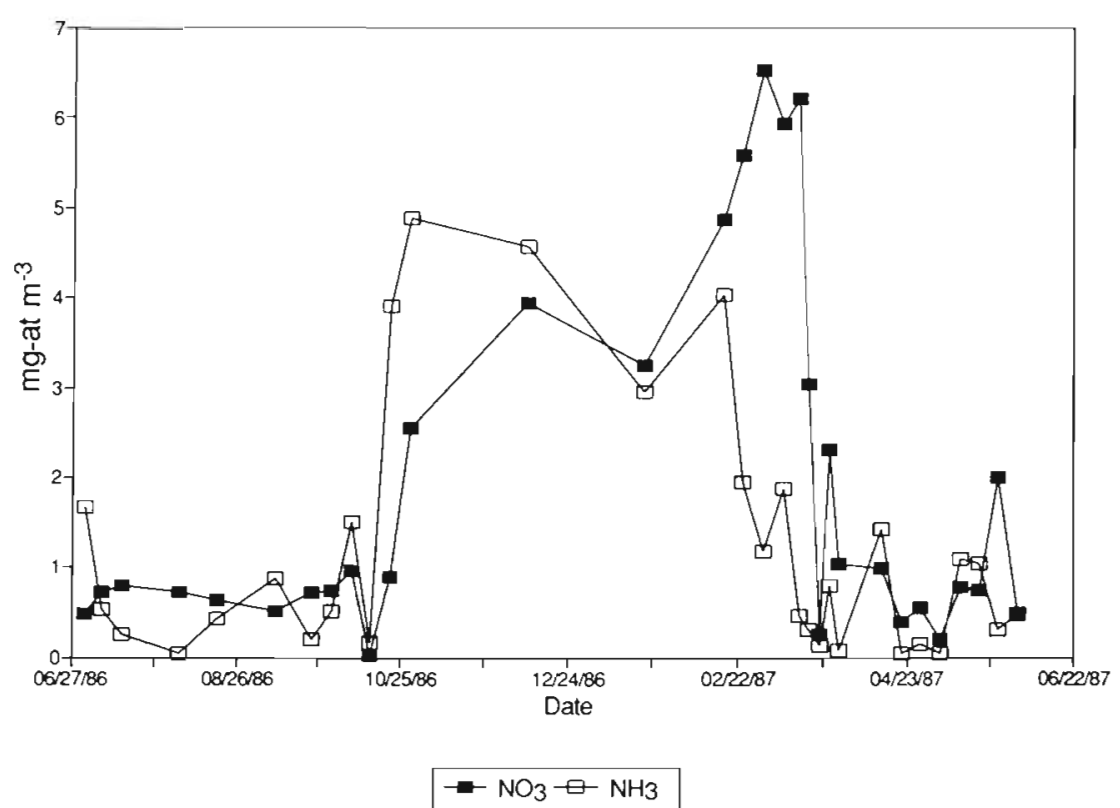

Fig. 2. Seasonal changes in primary production measured by the ${ }^{14} \mathrm{C}$ method, $\mathrm{CO}_{2}$ light-and-dark-bottle method, $\mathrm{O}_{2}$ light-and-dark-bottle method and chlorophyll concentration in Bedford Basin from July 1986 to June 1987

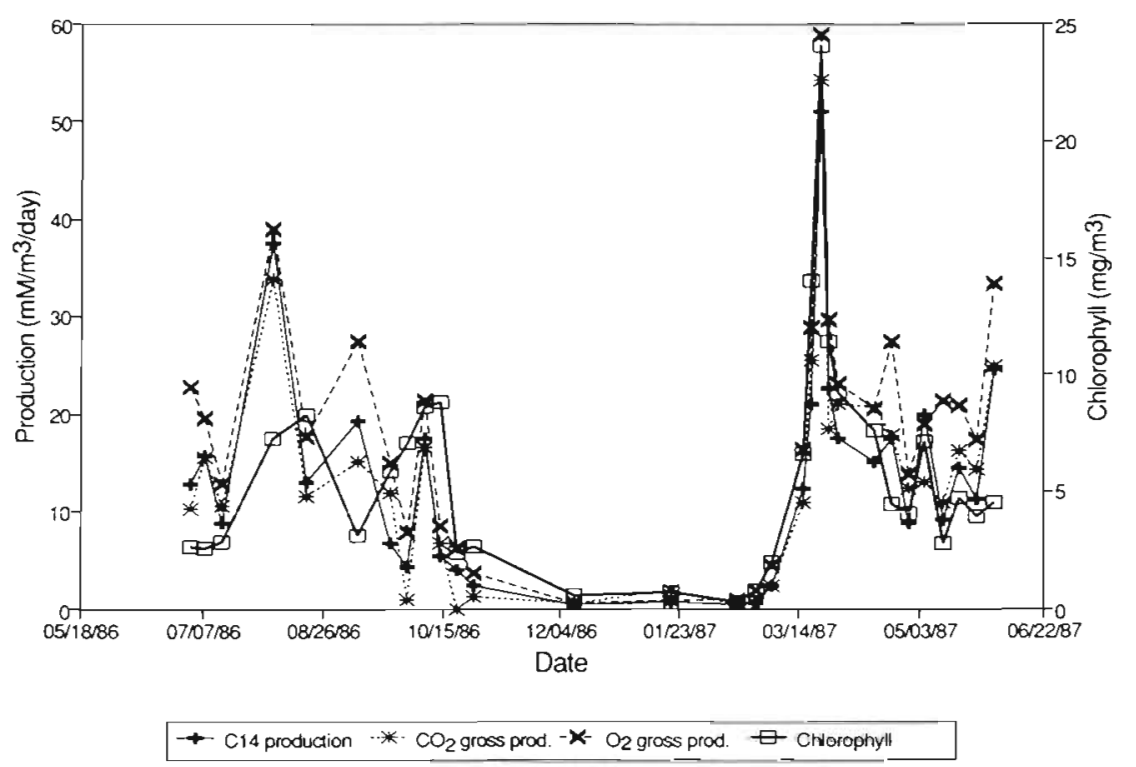

bited the same trends as primary production, reaching peak values of $59 \mathrm{mmol} \mathrm{O}_{2} \mathrm{~m}^{-3} \mathrm{~d}^{-1}$ and $54 \mathrm{mmol} \mathrm{C} \mathrm{m}^{-3}$ $\mathrm{d}^{-1}$ respectively during the spring bloom. In winter gross $\mathrm{CO}_{2}$ production was sometimes not measurable and gross oxygen production was $<1 \mathrm{mmol} \mathrm{O}_{2} \mathrm{~m}^{-3}$ $\mathrm{d}^{-1}$.

Photosynthetic quotient: Carbon-based indices of primary production can be intercalibrated against oxygen-based indices only within a factor equal to the photosynthetic quotient $(\mathrm{PQ})$ which is the molar ratio of oxygen and carbon production. It is expected (Williams et al. 1979, Davies \& Williams 1984) that PQ will vary according to the nature of the inorganic nitrogen source, higher values applying for nitrate utilisation than for ammonia utilisation. When ${ }^{14} \mathrm{C}$ carbon production was plotted against oxygen production (Fig. 3) it became apparent that the data could be separated into 2 groups, 0 to $10 \mathrm{mmol} \mathrm{C} \mathrm{m}{ }^{-3} \mathrm{~d}^{-1}$ and 10 to $50 \mathrm{mmol} \mathrm{C}$ $\mathrm{m}^{-3} \mathrm{~d}^{-1}$. Linear regression analysis of the 2 data sets gave slopes of 1.84 and 1.07 respectively. These slopes are estimates of the apparent PQ.

The majority of the observations in the first group ( 0 to $10 \mathrm{mmol} \mathrm{C} \mathrm{m}^{-3} \mathrm{~d}^{-1}$ ) were collected in winter (December to March) when chlorophyll biomass was low. This was the period of the year when ammonia concentrations were high and one would therefore 
Table 1. Primary production rates, inorganic nutrient concentrations and chlorophyll concentrations in Bedford Basin from July 1986 to June 1987

\begin{tabular}{|c|c|c|c|c|c|c|c|c|}
\hline Date & $\begin{array}{c}{ }^{14} \mathrm{C} \text { Prod. } \\
\left(\mathrm{mmol} C \mathrm{~m}^{-3} \mathrm{~d}^{-1}\right)\end{array}$ & $\begin{array}{c}\mathrm{CO}_{2} \text { gross } \\
\left(\mathrm{mmolCm}^{-3} \mathrm{~d}^{-1}\right)\end{array}$ & $\begin{array}{c}\mathrm{O}_{2} \text { gross } \\
\left(\mathrm{mmolO}_{2} \mathrm{~m}^{-3} \mathrm{~d}^{-1}\right)\end{array}$ & $\begin{array}{c}\mathrm{NO}_{3} \\
\text { ) (mg-at. m-3) }\end{array}$ & $\begin{array}{c}\mathrm{NH}_{3} \\
\left.\text { (mg-at. m }{ }^{-3}\right)\end{array}$ & $\begin{array}{c}\mathrm{Chl} \\
\left(\mathrm{mg} \mathrm{m}^{-3}\right)\end{array}$ & $\begin{array}{c}{ }^{14} \mathrm{CDOC} \\
\left(\mathrm{mmol} \mathrm{Cm}^{-3} \mathrm{~d}^{-1}\right)\end{array}$ & $\begin{array}{c}\mathrm{DOC} /{ }^{14} \mathrm{C} \\
(\%)\end{array}$ \\
\hline $2 \mathrm{JuI}$ & 12.8 & 10.2 & 22.8 & 0.48 & 1.66 & 2.65 & 1.00 & 8 \\
\hline $8 \mathrm{Jul}$ & 15.8 & 15.6 & 19.6 & 0.73 & 0.53 & 2.64 & 1.60 & 10 \\
\hline $15 \mathrm{JuI}$ & 8.8 & 10.6 & 12.9 & 0.79 & 0.24 & 2.87 & 1.00 & 12 \\
\hline $5 \mathrm{Aug}$ & 37.6 & 33.8 & 39.0 & 0.71 & 0.05 & 7.30 & 4.60 & 12 \\
\hline 19 Aug & 13.0 & 11.6 & 17.7 & 0.64 & 0.42 & 8.33 & 1.00 & 7 \\
\hline 9 Sep & 19.2 & 15.2 & 27.4 & 0.50 & 0.87 & 3.15 & 1.20 & 6 \\
\hline 23 Sep & 6.6 & 11.8 & 14.9 & 0.71 & 0.20 & 5.88 & 0.40 & 6 \\
\hline $30 \mathrm{Sep}$ & 4.2 & 1.0 & 7.9 & 0.74 & 0.52 & 7.04 & 0.40 & 6 \\
\hline 7 Oct & 17.4 & 16.6 & 21.4 & 0.97 & 1.50 & 8.59 & 1.00 & 6 \\
\hline 14 Oct & 5.4 & 6.8 & 8.6 & 0.02 & 0.16 & 8.79 & 0.40 & 6 \\
\hline $21 \mathrm{Oct}$ & 4.0 & 0.0 & 6.2 & 0.90 & 3.91 & 2.42 & 0.40 & 9 \\
\hline 28 Oct & 2.4 & 1.2 & 3.6 & 2.55 & 4.90 & 2.68 & 0.20 & 10 \\
\hline $10 \mathrm{Dec}$ & 0.4 & 0.6 & 0.6 & 3.94 & 4.57 & 0.62 & 0.80 & 19 \\
\hline $20 \mathrm{Jan}$ & 0.8 & 1.8 & 0.9 & 3.26 & 2.95 & 0.70 & 0.10 & 8 \\
\hline $17 \mathrm{Feb}$ & 0.4 & 0.4 & 1.0 & 4.87 & 4.03 & 0.33 & 0.10 & 20 \\
\hline $24 \mathrm{Feb}$ & 0.8 & 0.4 & 1.8 & 5.59 & 1.95 & 0.84 & 0.10 & 5 \\
\hline 3 Mar & 2.4 & 2.4 & 4.5 & 6.52 & 1.17 & 1.96 & 0.10 & 5 \\
\hline $10 \mathrm{Mar}$ & 2.6 & 2.4 & - & 5.93 & 1.88 & 2.82 & 0.10 & 5 \\
\hline $16 \mathrm{Mar}$ & 12.4 & 11.0 & 16.3 & 6.21 & 0.46 & 6.59 & 0.20 & 2 \\
\hline $19 \mathrm{Mar}$ & 21.0 & 25.6 & 28.9 & 3.04 & 0.30 & 14.04 & 0.60 & 2 \\
\hline $23 \mathrm{Mar}$ & 51.0 & 54.2 & 58.9 & 0.26 & 0.12 & 24.07 & 1.20 & 2 \\
\hline $26 \mathrm{Mar}$ & 22.6 & 18.4 & 29.7 & 2.30 & 0.79 & 11.43 & 0.40 & 2 \\
\hline $30 \mathrm{Mar}$ & 17.6 & 21.0 & 23.1 & 1.03 & 0.07 & 9.23 & 0.80 & 5 \\
\hline $14 \mathrm{Apr}$ & 15.0 & 20.6 & 20.5 & 0.98 & 1.42 & 7.59 & 0.40 & 2 \\
\hline $21 \mathrm{Apr}$ & 17.4 & 17.8 & 27.4 & 0.39 & 0.04 & 4.49 & 0.80 & 4 \\
\hline $28 \mathrm{Apr}$ & 8.8 & 12.4 & 13.8 & 0.55 & 0.14 & 4.07 & 0.40 & 4 \\
\hline 5 May & 19.8 & 13.0 & 19.0 & 0.19 & 0.05 & 7.17 & 1.20 & 6 \\
\hline $12 \mathrm{May}$ & 9.2 & 10.8 & 21.3 & 0.77 & 1.08 & 2.84 & 1.20 & 13 \\
\hline 19 May & 14.4 & 16.2 & 20.8 & 0.74 & 1.04 & 4.72 & 1.80 & 13 \\
\hline $26 \mathrm{May}$ & 11.2 & 14.2 & 17.3 & 1.99 & 0.30 & 3.98 & 1.60 & 13 \\
\hline 2 Jun & 24.6 & 24.8 & 33.4 & 0.45 & 0.48 & 4.53 & 1.60 & 6 \\
\hline
\end{tabular}

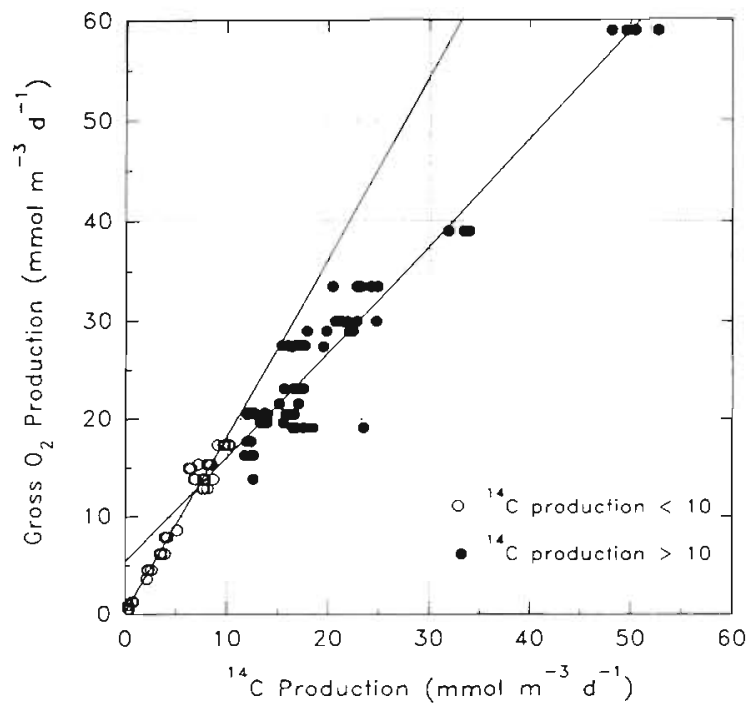

Fig. 3. Relationship between primary production measured by the oxygen light-and-dark-bottle method and the ${ }^{14} \mathrm{C}$ method in Bedford Basin from July 1986 to June 1987. Linear regressions are for 0 to $10 \mathrm{mmol}{ }^{14} \mathrm{C} \mathrm{m}^{-3} \mathrm{~d}^{-1}(0)$ and 10 to $50 \mathrm{mmol}$

$$
{ }^{14} \mathrm{C} \mathrm{m}^{-3} \mathrm{~d}^{-1}(\bullet)
$$

have expected to find low PQ values. At first examination the observed $P Q$ seems to be inconsistent with the observed nutrient regime.

Li \& Dickie (1987) have reported high concentrations of bacteria $\left(0.5\right.$ to $1.5 \times 10^{6}$ cells $\left.\mathrm{ml}^{-1}\right)$ during winter in Bedford Basin. Microzooplankton densities, although at their lowest in winter, are nevertheless quite high (Paranjape 1987). The light-and-dark-bottle oxygen method for estimating primary production assumes that the dark bottle measures only phytoplankton respiration. Clearly this is not the case in field studies. With low phytoplankton biomass and relatively high bacterial and microzooplankton biomass there is the potential to considerably overestimate primary production because of the higher 'community' respiration. Furthermore, Taguchi \& Platt (1977) have shown that assimilation of ${ }^{14} \mathrm{CO}_{2}$ in the dark increased dramatically during winter. In the present study, ${ }^{14} \mathrm{C}$ production was calculated by subtracting dark bottle counts from light bottle counts thereby introducing the potential for underestimating ${ }^{14} \mathrm{C}$ primary production.

The high apparent $P Q$ values observed when ${ }^{14} \mathrm{C}$ 
production rates were low are probably a result of overestimation of oxygen primary production and underestimation of ${ }^{14} \mathrm{C}$ primary production. For the remainder of the year the apparent $P Q$ value was 1.07 - a value consistent with a nutrient regime where ammonia concentrations were always measurable and concentrations frequently exceeded $0.5 \mathrm{mg}$-at. $\mathrm{m}^{-3}$.

Intercomparison of all 3 methods: Excellent agreement was found between the 2 carbon-based indices of primary production (Fig. 4). The data could be represented by the equation:

$$
P^{14} \mathrm{C}=0.708+0.938 P_{\mathrm{g}} \mathrm{CO}_{2}(\mathrm{n}=29)
$$

where $P_{\mathrm{g}} \mathrm{CO}_{2}$ and $P^{14} \mathrm{C}$ have units of mmol $\mathrm{C} \mathrm{m}^{-3} \mathrm{~d}^{-1}$. The intercept is not significantly different from zero. The slope is highly significant, and the equation explains $93 \%$ of the variance in $P_{\mathrm{g}} \mathrm{CO}_{2}$.

The only previous study to examine the 3 methods compared here, that of Bender et al. (1987), was carried out on laboratory mesocosm populations. In that study, primary production was monitored over a $24 \mathrm{~h}$ period by removing samples from the mesocosm at $4 \mathrm{~h}$ intervals beginning at dawn. In the first experiment, in which the mesocosm had been spiked with nutrients, it was found that $P_{\mathrm{g}} \mathrm{CO}_{2}$ and $P_{\mathrm{g}} \mathrm{O}_{2}$ gave excellent agreement with an apparent $P Q$ close to 1.0. This result is consistent with there being high concentrations of ammonia in the mesocosm. On the other hand, $P^{14} \mathrm{C}$ varied from 60 to $100 \%$ of $P_{\mathrm{g}}^{\mathrm{CO}_{2}}$ for incubation periods less than $24 \mathrm{~h}$. However, at the end of the $24 \mathrm{~h}$ experiments (the duration of the incubations in the present study), the estimates of $P_{\mathrm{g}} \mathrm{CO}_{2}$ and $P^{14} \mathrm{C}$ were very close (see their Figs. 1a and 4a). In the second experiment of Bender et al. (1987), where the mesocosm had not been

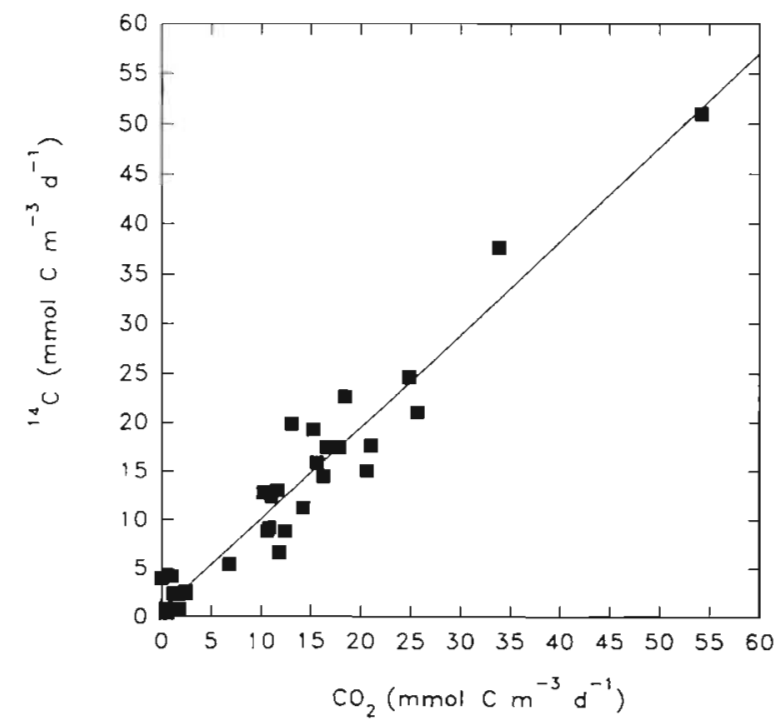

Fig. 4. Relationship between primary production measured by the $\mathrm{CO}_{2}$ light-and-dark-bottle method and the ${ }^{14} \mathrm{C}$ method in Bedford Basin from July 1986 to June 1987 loaded with nutrients, the estimates of $P_{\mathrm{g}}^{\mathrm{CO}_{2}}$ and $P^{14} \mathrm{C}$ agreed well for most of the $24 \mathrm{~h}$ period. This is the experiment that probably corresponds more closely to the present series of observations on natural assemblages of phytoplankton.

Conclusions. In the range of primary production rates from 2 to $50 \mathrm{mmol} \mathrm{C} \mathrm{m} \mathrm{C}^{-3}$, the coulometric method agreed very well with the ${ }^{14} \mathrm{C}$ method for $24 \mathrm{~h}$ in situ incubations, and it can therefore be recommended as a viable alternative to the ${ }^{14} \mathrm{C}$ method for situations where it is not convenient or possible to use radioactive isotopes. Furthermore, the method has the ability to estimate gross (dark bottle minus light bottle) and net (time-zero minus light bottle) production and respiration (dark bottle minus time-zero) which the ${ }^{14} \mathrm{C}$ method cannot. Preliminary experiments at production rates below $2 \mathrm{mmol} \mathrm{C} \mathrm{m}^{-3} \mathrm{~d}^{-1}$ indicate that this is the effective lower limit of the method.

The agreement between the 2 carbon-based indices of primary production and the oxygen-based one, to within an apparent photosynthetic quotient in the range from 1 to 2.0, lends further support to the validity of the data from the coulometric method. Furthermore, the method has the ability to estimate gross and net production and respiration which the ${ }^{14} \mathrm{C}$ method cannot. Note however that all 3 methods are vulnerable to errors arising from containment of samples in glass bottles, and for this reason none of them can be considered as the standard against which the others should be judged. If containment errors do bias the data, it appears that they affect all 3 methods in the same way. Lack of an absolute standard for primary production measurements will continue to impede the progress of biological oceanography and to lead to controversy over the interpretation of oceanographic data.

Acknowledgements. The author thanks Drs T. Platt, W. G. Harrison and R. Moore for their encouragement and support in the preparation of this manuscript and J. Anning, $C$. Caverhill, A. Macdonald and G. N. White, III for their assistance in sample collection and analysis.

\section{LITERATURE CITED}

Bender, M., Grande, K., Johnson, K., Marra, J., Williams, P. J. LeB., Sieburth, J., Pilson, M., Langdon, C., Hitchcock, G., Orchardo, J., Hunt, C., Donaghy, P., Heineman, K. (1987). A comparison of four methods of determining planktonic community production. Limnol. Oceanogr. 32: 1085-1098

Davies, J. M., Williams, P. J. LeB. (1984). Verification of ${ }^{14} \mathrm{C}$ and $\mathrm{O}_{2}$ derived primary production measurements using an enclosed ecosystem. J. Plankton Res. 6: 457-474

Irwin, B., Caverhill, C., Anning, J., Mossman, D., Platt, T. (1988a). Carbon and oxygen primary production in Bedford Basin, Nova Scotia from March to June 1985. Can. Data Rep. Fish. Aquat. Sci. 686: 135p. 
Irwin, B., Caverhill, C., Dickie, P., Horne, E., Platt, T. (1986). Primary production on the Labrador Shelf during June and July 1984. Can. Data Rep. Fish. Aquat. Sci. 577: 162p.

Irwin, B., Anning, J., Caverhill, C., Escribano, R., Platt, T. (1988b). Carbon and oxygen primary production in Bedford Basin from January to April 1986. Can. Data Rep. Fish. Aquat. Sci. 719: 34p.

Irwin, B., Harrison, W. G., Platt, T. (1983). Plankton dynamics in Bedford Basin, Nova Scotia; phytoplankton productivity experiments and nutrient measurements from February 13, 1978 to March 14, 1979. Can. Data Rep. Fish. Aquat. Sci. 272: 175p

Johnson, K. M., King, A. E., Sieburth, J. McN. (1985). Coulometric $\mathrm{TCO}_{2}$ analyses for marine studies; an introduction. Mar. Chem. 16: 61-82

Johnson, K. M., Sieburth, J. McN., Williams, P. J. LeB., Brandstrom, L. (1987). Coulometric total carbon dioxide analysis for marine studies: automation and calibration. Mar. Chem. 21: 117-133

Li, W. K. W., Dickie, P. M. (1987). Temperature characteristics of photosynthetic and heterotrophic activities: seasonal variations in temperate microbial plankton. App. environ. Microbiol. 53: 2282-2295

Paranjape, M. A. (1987). The seasonal cycles and vertical distribution of tintinnines in Bedford Basin, Nova Scotia, Canada. Can. J. Zool. 65: 41-48

Peterson, B. J. (1980). Aquatic primary productivity and the

This note was presented by T. Platt, Dartmouth, N.S., Canada
${ }^{14} \mathrm{CO}_{2}$ method: a history of the productivity problem. Ann Rev. Ecol. Syst. 11: 369-385

Platt, T. (1984). Primary productivity in the Central North Pacific: comparison of oxygen and carbon fluxes. Deep Sea Res. 31: 1311-1319

Platt, T., Harrison, W. G. (1986). Reconciliation of carbon and oxygen fluxes in the upper ocean. Deep Sea Res. 33: $273-276$

Platt, T., Harrison, W. G., Lewis, M. R., Li, W. K. W., Sathyendranath, S., Smith, R. E., Vézina, A. F. (1989). Biological production of the oceans: the case for a concensus. Mar. Ecol. Prog. Ser. 52: 77-88

Smith, R. E. H., Harrison, W. G., Irwin, B., Platt, T. (1986). Metabolism and carbon exchange in microplankton of the Grand Banks (Newfoundland). Mar. Ecol. Prog. Ser. 34: 171-183

Strickland, J. D. H., Parsons, T R. (1972). A practical handbook of seawater analysis. Bull. Fish. Res. Bd Can. 167

Taguchi, S. Platt, $\mathrm{T}(1977)$. Assimilation of ${ }^{14} \mathrm{CO}_{2}$ in the dark compared to phytoplankton production in a small coastal inlet. Estuar. coast. mar. Sci. 5: 679-684

Williams, P. J. LeB., Jenkinson, N. W. (1982). A transportable microprocessor-controlled Winkler titration suitable for field station and ship board use. Limnol. Oceanogr. 27: 576-584

Williams, P. J. LeB., Rorne, R. C. T., Bryan, J. R. (1979). Agreement between the ${ }^{14} \mathrm{C}$ and oxygen methods of measuring phytoplankton productions: reassessment of the photosynthetic quotient. Oceanologica Acta 2: 411-416

Accepted: January 8, 1991 